\title{
PROJECT FOR THE PUBLICATION OF MISSION ARCHIVES
}

In 1980 three missionary organizations in the Netherlands, the Raad voor de Zending der Nederlandse Hervormde Kerk, the Gereformeerde Zendingsbond in de Hervormde Kerk and the Zending der Gereformeerde Kerken, decided to appoint a mission historian charged with the inventarization (when this had not already been done) and publication of the archives in their care. It is planned that these archives should be published in both Dutch and Indonesian. The organizations took this decision at the request of the Indonesian churches, but also as a result of the experience of students and scholars of various disciplines, who were continually surprised at the richness of material in the archives. The execution of this project was entrusted to Dr. T. van den End, who from 1970-1981 had been employed by the Theological College in Jakarta as a church historian. While there, he had been active translating material on Church and Mission history into Indonesian.

In the first stage of the project, which was begun in 1982, Dr. van den End has been ordering and inventarizing the archive of the Gereformeerde Zendingsbond, which, from 1913, worked in the Sa'dan-Toraja area of South Sulawesi. The next stage will be the selection and annotation of documents from the archives for publication. The resulting volume will be translated into Indonesian. When this work in the GZB archives has been completed, work will begin in the archives of one of the societies, which around 1950 were incorporated in the Zending der Nederlandse Hervormde Kerk, either the Nederlandse Zendingsvereniging, which worked in West Java and South-east Sulawesi, or the Utrechtse Zendingsvereniging, which was active in Irian and Halmahera.

Information of this project can be obtained from $\mathrm{Dr}$. T. van den End, Wendenlaan 6, 7315 DP Apeldoorn, tel. 055211531. 